\title{
Greater Britain: A Useful Category of Historical Analysis?
}

\section{Citation}

Armitage, David. 1999. Greater Britain: A useful category of historical analysis? American Historical Review 104(2): 427-445.

\section{Published Version}

http://dx.doi.org/10.2307/2650373

\section{Permanent link}

http://nrs.harvard.edu/urn-3:HUL.InstRepos:3206299

\section{Terms of Use}

This article was downloaded from Harvard University's DASH repository, and is made available under the terms and conditions applicable to Other Posted Material, as set forth at http:// nrs.harvard.edu/urn-3:HUL.InstRepos:dash.current.terms-of-use\#LAA

\section{Share Your Story}

The Harvard community has made this article openly available.

Please share how this access benefits you. Submit a story.

\section{Accessibility}




\title{
AHR Forum
}

\section{Greater Britain: A Useful Category of Historical Analysis?}

\author{
DAVID ARMITAGE
}

THE FIRST "BRITISH" EMPIRE imposed England's rule over a diverse collection of territories, some geographically contiguous, others joined to the metropolis by navigable seas. The various peoples who inhabited those territories were not all treated alike by English colonists, who extended their power by military aggression. At first, a commission to evangelize pagan populations had legitimated English expansion; subsequently, a cultural mission to civilize the barbarian maintained the momentum of conquest; later still, an ideology of domination and a historical mythology together encouraged further English migration and the resettlement of native peoples on the conquered lands. Although the English did export their governing institutions, the exigencies of colonial rule demanded that control of the outlying territories be left in the hands of absentee proprietors or entrusted to a creolized governing elite. That elite in time grew to demand its independence, and appropriated legislative institutions to affirm its autonomy. The English nonetheless remained the cultural arbiters and commercial masters of what remained formally an Anglo-British empire, over which they steadfastly asserted their sovereignty. They had acquired this empire haphazardly and with little determining forethought. Within two centuries of its inception, it had disintegrated, apparently for good. Failure to enforce institutional uniformity, incomplete assimilation of subject peoples, the cultural estrangement of the English settlers from metropolitan norms, and monarchical indifference all conspired to bring about its collapse.

Even though such a narrative of colonial expansion, cultural divergence, and imperial implosion might seem to fit that of the British Atlantic empire of the seventeenth and eighteenth centuries, it in fact describes the "British" empire that reached its apogee in the reign of Edward I (1272-1307), not the one reconstituted under George III (1760-1820). Its dependencies were not the colonies of British North America, the western Atlantic, and the Caribbean but rather Ireland, Wales, and Scotland, the constituent kingdoms and principalities of the northwest European archipelago. ${ }^{1}$ Yet the very fact that the structure of this medieval narrative so

I am especially grateful to the National Humanities Center for its support during the original composition of this article. My thanks, too, to Joyce Chaplin, Jack P. Greene, Elizabeth Mancke, John Sainsbury, Anders Stephanson, and the $A H R$ 's anonymous reviewers for their comments on earlier versions. Finally, I am indebted to Richard L. Bushman for his generosity and willingness to share the experience of teaching the history of Greater Britain.

I R. R. Davies, "The Failure of the First British Empire? England's Relations with Ireland, Scotland and Wales 1066-1500," in Nigel Saul, ed., England in Europe, 1066-1453 (London, 1994), 121-32; 
closely parallels another in early modern British and colonial American history indicates the close connections between European state formation and extraEuropean empire building in the pre-modern period. ${ }^{2}$ Conventional historical accounts of the consolidation of European nation-states and the expansion of those states beyond Europe have tended to obscure the continuity between the two processes, both as they were projected outward from metropolitan centers and as they were experienced by provinces, colonies, and dependencies. ${ }^{3}$ Early modern empire building was an cxtension of state formation, although the one did not necessarily follow smoothly from the other. As the American Revolution showed, an empire could split apart when the demands of the state came into conflict with the aspirations of a wider British nation. Empire therefore revealed the limits of any equation between nation and state. ${ }^{4}$

The disjuncture between national and extra-national histories has been particularly abrupt within the history of Britain. None of the major modes of English historiography in the nineteenth century and most of the twentieth had any place for the imperial enterprise. An insular history of English exceptionalism maintained a willful amnesia about England's outlying dependencies, whether British, Irish, continental European, or ultramarine. 5 The historiography of English religion grounded such exceptionalism in an Erastian tradition that could be extended back to Bede, or at least to John Wycliffe, but that had gained its true distinctiveness and its enduring embodiment in the Church of England, born, Athena-like, from the head of Henry VIII at the English Reformation. ${ }^{6}$ The parallel whig narrative of constitutional development provided an institutional account of the reasons for England's apartness while also appealing to geographical determinism as a partial explanation for the peculiar resilience of England's constitution. In the words of John Burrow, "Empire [was] not salient in Whig history."7 Isolationist imperialism remained vigorous well into the twentieth century: Herbert Butterfield suggested in 1944 that "the real alternative to whig history in recent times-- the real tory alternative to the organization of English history on the basis of the growth of

compare Davies, Domination and Conquest: The Experience of Ireland, Scotland and Wales, 1100-1300 (Cambridge, 1990); Robin Frame, The Political Development of the British Isles, 1100-1400 (Oxford, 1990); A. F. McC. Madden, "1066, 1776 and All That: The Relevance of English Medieval Experience of 'Empire' to Later Imperial Constitutional Issucs," in John E. Flint and Glyndwr Wiliams, cds., Perspectives of Empire: Essays Presented to Gerald S. Graham (London, 1973), 9--26.

2 Though for important caveats, see Jack P. Grcene, Peripheries and C'enter: Constitutional Development in the Extended Polities of the British Empire and the United States, 1607.-1788 (Athens, Ga., 1986), 8-9.

${ }^{3}$ Robett Bartlett, The Making of Europe: Conquest, Colonization and Cultural Change, 950-1350 (Princeton, N.J., 1993), is an inspiring exception to this general observation; the program suggested in Merri]l Jensen and R. L. Reynolds, "European Colonial Experience: A Plea for Comparative Studies," Studi in onore di Gino Luzzatto 4 (Milan, 1951), 75-90, has yet to be followed through in detail.

4 Jack P. Greene, The British Revolution in America (Austin, Tex., 1996); Eliga H. Gould, "A Virtual Nation: Greater Britain and the Imperial Iegacy of the American Revolution,"AHR 104 (April 1999):
476-89.

5 J. G. A. Pocock, "The Limits and Divisions of British History: In Search of the Unknown Subject," AHR 87 (April 1982): 311-14.

"Michael Bentley, "The British State and Its Historiography," in Wim Blockmans and Jean-Ptilippe Genet, eds., Visions sur le développement des états européens: Théories et historiographies de l'état moderne (Rome, 1993), 1.54, 162-64.

7 J. W. Burrow, A Liberal Descent: Victorian Historians and the English Past (Cambridge, 1981), 233. 
liberty -was the story of British expansion overseas." But even he realized that "the shock of 1940" had shaken the English from their narrowly whiggish slumber only to discover that the history of the British Empire was in fact the extension of the history of liberty, not the alternative to it. ${ }^{8}$ By 1944, it was almost too late for such a reconstruction of the English history of liberty as a British history of empire, Winston Churchill's long-meditated History of the English-Speaking Peoples (195658 ) and Arthur Bryant's even more belated History of Britain and the British Peoples (1984-90) notwithstanding. ${ }^{9}$ Historians on the left, suspicious of the paternalist claims made on behalf of the British Empire, yet embarrassed by the part played by the empire in shaping a conservative patriotism, all but avoided the subject. ${ }^{10}$ Only with the end of the empire would the necessary rewriting of English, British, and imperial histories become both viable and generally acceptable; only in the last two decades has that review actually begun to take shape. ${ }^{11}$

How COULD THE HISTORY OF THE BRITISH EmpiRe-state be written? J. R. Seeley's Expansion of England (1883) offered one possible model. As every schoolchild once knew, Seeley's compact volume was one of the best of all best-sellers in late Victorian Britain. Seelcy had presented his theses as two sets of lectures to Cambridge undergraduates in 1881-1882, and would have left them unpublished were it not for the urging of Florence Nightingale. The book remained in print until 1956 (the year of the Suez crisis), returned to circulation in 1971, and has only recently lapsed once more. ${ }^{12}$ Seeley is still remembered by historians of the British Empire as the founding father of their subfield; ${ }^{13}$ historians of Britain have also

${ }^{8}$ Maurice Cowling, Religion and Public Doctrine in Modern England, vol. 1 (Cambridge, 1980), 214; Herbert Butterfield, The Englishman and His History (Cambridge, 1944), 81-82; J. C. D. Clark, "National Identity, State Formation and Patriotism: The Role of History in the Public Mind," History Workshop Journal 30 (1990): 95.

${ }^{9}$ Winston Churchill, A History of the English-Speaking Peoples, 4 vols. (London, 1956-58); Arthur Bryant, The History of Britain and the British Peoples, 3 vols. (London, 1984-90).

i" Stephen Howe, "Labour Patriotism, 1939-83," in Raphael Samuel, ed., Patriotism: The Making and Unmaking of British National Identity, Vol. 1: History and Politics (London, 1989), 127-39. The absence is especially conspicuous in the work of Christopher Hill, Lawrence Stone, and E. P. Thompson, each of whom has written about the empire only very belatedly in their long careers: for example, Hill, Liberty against the Law: Some Seventeenth-Century Controversies (London, 1996), pt. 3, "Imperial Problems"; Stone, "Introduction," in Lawrence Stone, ed., An Imperial State at War: Britain from 1689 to 1815 (London, 1994), 1-32; 'l'hompson, "Alien Homage": Edward Thompson and Rabindranath Tagore (Delhi, 1993); Robert Gregg and Madhavi Kale, "The Empire and Mr Thompson: Making of Indian Princes and English Working Class," Economic and Political Weekly 33, 36 (September 6-12, 1997): 2273-88.

"For synoptic evidence of this, see Nicholas Canny, ed., The Oxford History of the British Empire, Vol. 1: The Origins of Empire (Oxford, 1998); P. J. Marshall, ed., The Oxford Histury of the British Empire, Vol. 2: The Eighteenth Century (Oxford, 1998); Andrew Porter, ed., The Oxford History of the British Empire, Vol. 3; The Nineteenth Century (Oxford, 1999); Judith M. Brown and Wm. Roger Louis, eds., The Oxford History of the British Empire, Vol. 4: The Twentieth Century (Oxford, 1999).

12 J. R. Seeley, The Expansion of England [1883], John Gross, ed. (Chicago, 1971); Deborah Wormell, Sir John Seeley and the Uses of History (Cambridge, 1980), 93-98, 154-65.

13 Peter Burroughs, "John Robert Seeley and British Imperial History," Journal of Imperial and Commonwealth History 1 (1972): 191-211; J. G. Greenlee, "A 'Succession of Seeleys': The 'Old School' Re-examined," Joumal of Imperial and Commonwealth History 4 (1976): 266-82; David Ficldhouse, "Can Humpty-Dumpty Be Put Together Again? Reflections on Impcrial History in the 1980s," Journal of Imperial and Commonwealth History 12 (1984): 9. 
begun to recall him from the intellectual oblivion into which he had slipped. ${ }^{14}$ Seeley protested against just the separation of domestic and imperial history that these recent successors have also deplored. In particular, he condemned the whiggish introversion of his contemporaries who "make too much of mere parliamentary wrangle and agitations about liberty" in the ejghteenth century but "do not perceive that in that century the history of England is not in England but in America and Asia." 15 By shifting the horizons of historiography, Seeley hoped to create-or even recreatc - a consciousness among his listeners and readers that they were inhabitants not of little England but rather of "Greater Britain."

Although Seeley put the term "Greater Britain" into general currency, he had not coined it. The credit for its invention goes to Sir Charles Dilke, whose imperial travelogue of 1868 had used it to describe the colonies of white settlement through which he had earlier toured.to Seeley's strictly armchair survey of the same territories encompassed the Canadian Confederation, the West Indies, southern Africa (especially the Cape Colony), Australia, and New Zealand as part of an "ethnological unity" with "England" that was held together as a community by common ties of "race" (or "nationality"), religion, and "interest." 17 There were many peculiarities in Seeley's conception of Greater Britain. He excluded India, because it had been acquired by conquest rather than settlement, although he still included the West Indies and Australia. He described the settlements as racially homogeneous--far from true even for the white settler populations, which included the francophone Québécois and the Boers of the Cape. He also assumed a community of interest between whitc Britons at home and abroad that would not be tested until World War I some thirty years later. Even though Seeley's work gave comfort to the Imperial Federation movement of the $1880 \mathrm{~s}$, on whose political fringes he operated, his main aim was to effect an expansion of the English historical imagination, particularly as it remembered the eighteenth century. He argued forcefully that Greater Britain was the eighteentl century's legacy to the nineteenth, "the single monument of a state of the world which has almost passed away." 18 The English had striven to forget this fact, but Greater Britain would not be overlooked so easily.

The political conception of Greater Britain lasted only as long as the hopes for Imperial Federation, just as the decline in the popularity of Seeley's work followed the same trajectory as the British Empire itself. Why, then, should his ideas matter

\footnotetext{
${ }^{14}$ Bernard Baityn and Plilip D. Morgan, "Introduction," in Bailyn and Morgan. eds., Strungers within the Realm: Cultural Margins of the First British Enpire (Chapel Hill, N.C., 199i), 1-2; Linda Colley, The Significance of the Frontier in British History (Austin, Tex., 1995), 7-8; Philip Lawson, "Sources, Schools and Separation: The Many Faces of Parliament's Role in Anglo-American History to 1783," in I,awson. ed., Parlianent and the Atlantic Empire (Edinburgh, 1995), 11-12; Bill Schwarz, "Introduction: The Expansion and Contraction of England," in Schwarz, ed., The Expansion of England: Race, Ethnicity and Cultural History (London, 1996), 2-4; Keith Robbins, Great Britain: Identities, Institutions and the Idea of Britishness (London, 1998), 211-12.

15 Seelcy, Expansion of England, 12, 13.

in (.. W. Dilks, Greater Britain: A Record of Thavel in the English-Speaking Conntries during 1866 and '67, 3 vols. (London, 1868); Dilke, Problems of Greater Britain (London, 1890). The tern was later appropriated, for very different ends, by Sir Oswald Mosley, The Greater Briatin (London, 1932). My thanks to Chris Waters for pointing this out.

17 Seeley, Expansion of England, 15, 43-44.

is Seeley, Expansion of England, 39.
} 
now? Why should historians of Britain and the Atlantic world pay any attention to a long-dead English Latin professor turned historian, whose political vision was utopian and whose other major works are mostly slumbering memorials to evangelical Broad Churchmanship, Victorian Prussophilia, and introverted diplomatic history ${ }^{19}$ One reason is the family resemblance between Seeley's vision of "Greater Britain" and J. G. A. Pocock's appeals, almost a century later, for a new approach to British history. Beginning in 1973, Pocock began to call for a "new subject" of "British history" that paid equal attention to both the interactions of peoples, nations, and states within the "Atlantic archipelago" and the extension of those interactions across the maritime expanses of the Atlantic, Pacific, and Indian Oceans. The long, withdrawing roar of empire could be heard behind this plea, which Pocock first made in New Zealand, in the voice of an aggrieved and abandoned New Zealander. The decision by Edward Heath's Conservative government that Britain should become a full member of the European Economic Community in January 1973 demanded British entry to a Common Agricultural Policy. This benefited European farmers but thereby blocked cheap imports from the Commonwealth, with obvious economic consequences for former beneficiaries of imperial preferences like the sheep farmers of New Zealand and more subtle psychological effects for their compatriots like Pocock. ${ }^{20}$

Pocock's "New British History" would be a history of Greater Britain as a fluid, dynamic, and interactive system, rather than the majestically static "ethnological" union Seeley had envisaged. It would recover the white settler communities of the former British Empire from the distant verges of the globe, so that by encompassing them within an imperial past they might remain partners in a Commonwealth present. It explicitly defined Britain as an oceanic entity that looked to the west and the south, and whose connections with Europe were implicitly accidents of submarine geology rather than a determining set of relations (this despite the fundamental place of French and Italian humanism within Pocock's own two most influential books).21 Pocock's "New British History" therefore attempted the revivification of British history as an imperial history, both within Britain and Ireland and across the oceans; however, it still gave comfort to a species of Euro-skeptical exceptionalism, now cast as the attribute of Greater Britain rather than of little England.

The New British History has now borne fruit, a quarter-century after Pocock first planted the seeds in New Zealand. That fruit has mostly fallen in the gardens of

11 [J. R. Seeley], Ecce Homo: A Survey of the Life and Work of Jesus Christ (London, 1865); Secley, The Life and Times of Stein, or Germany and Prussia in the Napoleonic Age, 3 vols. (Cambridge, 1878); Seeley, The Growth of British Policy: An Historical Essay, 2 vols. (Cambridge, 1895).

20 J. G. A. Pocock, "British History: A Plca for a New Subject," New Zealand Historical Joumal 8 (1974): 3-21; Pocock, "History and Sovereignty: The Historiographic Response to Europeanization in Two British Cultures," Journal of British Studies 31 (1991): 361-64, 380-89; Pocock, "Deconstructing Europe," London Review of Books (December 19, 1991): 6-10.

21 J. G. A. Pocock, The Ancient Constitution and the Feudal Law: A Study of English Historical Thought in the Seventeenth Century: A Reissue with a Retrospect (Cambridge, 1987), chap. 1; Pocock, The Machiavellian Moment: Florentine Political Though and the Atlantic Republican Tradition (Princeton, N.J., 1975), chaps. 4-9. 
British and Irish historians, however. "England" can no longer be used as a synecdoche for "Britain," let alone for "Britain and Ireland"; what was once the marginal "Celtic fringe" to English historians is now the encompassing "Celtic crescent" around the southeastern English core-state. ${ }^{22}$ England is now rightly recognized as but one among three kingdoms and at least four nations that have coalesced, colluded, and collided within what, in the aftermath of the Good Friday Agreement in Northern Ireland, we are now encouraged to call the "Islands of the North Atlantic" (IONA). ${ }^{23}$ The theological complexities of incorporating four (or more) nations into Three (or fewer) Kingdoms bedeviled politicians throughout the early modern period; the solution to such dilemmas eluded those politicians as long as they clung to essentially English notions of unitary parliamentary sovereignty; historians equipped with hindsight have been more open to alternatives, even if some (like J. C. D. Clark) have preferred to assume the hegemony of the English Anglican-Parliamentary Leviathan since the Reformation, both within Britain and Ireland and outward into the Atlantic world. ${ }^{24}$ Yet one important result of the New British History might have been comparative rather than integrative. The Three Kingdoms present an ideal opportunity for internal comparisons within geographically circumscribed conditions. ${ }^{25}$ As yet, this possibility has been mostly exploited by economic historians, even though England has rarely been considered as one of the objects of comparison. ${ }^{26}$ The disunity that preceded, accompanied, and later succeeded the brief parliamentary union of Britain and Ireland between 1801 and 1922 offers less evidence of an obstinate teleology of integration than of a persistent history of interaction. It therefore rebukes English exceptionalism even as it palliates Anglo-British self-congratulation.

The opportunity for comparative histories of the Three Kingdoms has nevertheless rarely been taken, largely because of the statist assumptions that underlie most of the New British History of the early modern period. As Jane Ohlmeyer notes in this Forum, "[t]o date, the New British and Irish Histories have focused on political developments, such as state formation and the impact of the Protestant reformation in Ireland." 27 They have therefore reproduced the categories of nineteenth-century

${ }^{22}$ Michael Hechter, Internal Colonialism: The Celtic Fringe in British National Development 15361966 (London, 1975); Michael Perceval-Maxwell, "Ireland and the Monarchy in the Early Stuart Multiple Kingdon," Historical Joumal 34 (1991): 279-95; Jenny Wormald, "The Creation of Britain: Multiple Kingdoms or Core and Colonies?" Transactions of the Royal Historical Society, 6th ser., 2 (1992): 175-94; Allan Macinnes, "Gaelic Cuiture in the Seventecnth Century: Polarization and Assimilation," in Steven G. Ellis and Sarah Barber, eds., Conquest and Union: Fashioning a British State, 1485-1725 (Jondon, 1995), 162-94.

${ }^{23}$ Fintan O'Toole, "The Meanings of Union," New Yorker (April 27 and May 4, 1998): 61.

24 J. C. D. Clark, The Langlage of Liberty, 1660-1832: Political Discourse and Social Dynamics in the Anglo-American World (Cambridge, 1995).

25 J. H. Elliott, National and Comparative History: An Inaugural Lecture Delivered before the University of Oxford on 10 May 1991 (Oxford, 1991); Elliott, "Comparative History," in Carlos Barros, ed., Historia a Debate, Vol. 3: Otros Enfoutses (Santiago de Compostela, 1995), 9-19.

26 Notable exceptions include L. M. Cullen and T. C. Smout, eds., Comparative Aspects of Irish and Scottish Economic Development (Edinburgh, 1977); and Rosalind Mitchison and Paul Roebuck, eds., Economy and Society in Scotland and Ireland, 1500-1939 (Edinburgh, 1988); however, Keith Wrightson, "Kindred Adjoining Kingdoms: An English Perspective on the Social and Economic History of Early Modern Scotland," in R. A. Houston and 1. D. Whyte, eds., Scottish Society, 1500-1800 (Cambridge, 1989), 245-60, seems to have encouraged few imitators.

27 Jane Ohlmeyer, "Seventeenth-Century Ireland and the New British and Atlantic Histories," $A H R$ 104 (April 1999): 449. 
historiography without actually transcending them and have retained the form even as they have challenged the substance of the preceding historiography. The abundance of scholarship on the mid-seventeenth-century crisis owes a particular debt to the European model of "composite monarchy" derived from the work of J. H. Elliott and H. G. Koenigsberger, which has been found more broadly applicable to state formation throughout early modern Europe. ${ }^{28}$ This model has greatly illuminated the instabilities within the state system ruled, lost, and then ruled again by the Stuart monarchs of the seventeenth century, although critics among Scottish and Irish historians have complained that it has not yet provided the multicentered perspective necessary to explode Anglocentric exceptionalism. ${ }^{29}$

Perhaps because they have a stake in avoiding the state-centered narrative that for so long informed English history, historians of Ireland have been at the forefront of attempts to take Ireland out of "British" history in order to restore it in common patterns of European history. This goal, however, has been achicved partly at the expense of the Atlantic model of Irish history associated with the work of David Beers Quinn and Nicholas Canny. ${ }^{30}$ This model has itself been criticized for stranding Ireland in the Atlantic as that "famous island set in a Virginian Sea," thereby involving it in a framework of colonial dependency on England, like New England or New Spain, rather than making it comparable to the outlying territories of other European composite monarchies such as Naples or Bohemia. ${ }^{31}$ Raymond Gillespie's suggestion that early modern Ireland be treated "as a mid-Atlantic polity having some of the features of both the Old World and the New," yet fully part of neither, aptly captures the ambiguity of Ireland's position without ruling its peculiarities out of consideration or rendering it utterly exceptional and hence strictly incomparable to other patterns of early modern social and political development. ${ }^{32}$

Historians of Ireland aside, practitioners of the New British History have been

${ }^{28}$ J. H. Elliott, The Revolt of the Catalans: A Study in the Decline of Spain, 1598-1640 (Cambridge, 1963); Elliott, "A Europe of Composite Monarchies," Past and Present 137 (November 1992): 48-71; H. G. Koenigsberger, "Dominium Regale or Dominium Politicum et Regale: Monarchies and Parliaments in Early Modern Europe" [1975], in Koenigsberger, Politicians and Virtuosi: Essays in Early Modern History (London, 1986), 1-25; Koenigsberger, "Composite States, Representative Institutions and the American Revolution," Historical Research 62 (1989): 135-54.

${ }^{29}$ Conrad Russell, The Fall of the British Monarchies, 1637-1642 (Oxford, 1991); Keith Brown, "British History: A Sceptical Comment," in Ronald Asch, ed., Three Nations-A Common History? England, Scotland, Ireland and British History, c. 1600-1920 (Bochum, 1993), 117-27; Nicholas Canny, "Irish, Scottish and Welsh Responses to Centralisation, c. 1530-c. 1640: A Comparative Perspective," in Alexander Grant and Keith J. Stringer, eds., Uniting the Kingdom? The Making of British History (London, 1995), 148.

30 D. B. Quinn, "Ireland and Sixteenth Century European Expansion," in T. Desmond Williams, ed., Historical Studies 1 (London, 1958), 21-32; Quinn, The Elizabethans and the Irish (Ithaca, N.Y., 1966); Quinn, Ireland and America: Their Early Associations, 1500-1640, Liverpool Historical Essays 6 (Liverpool, 1991); Nicholas Canny, Kingdom and Colony: Ireland in the Atlantic World, 1560-1800 (Baltimore, Md., 1988); Canny, Making Ireland British, 1580-1650 (Oxford, forthcoming).

31 The phrase is Fynes Moryson's, quoted in Canny, Kingdom and Colony, 131; Hiram Morgan, "Mid-Atlantic Blues," Irish Review 11 (1991-92): 50-55; John Morrill, "The British Problem, $c$. 1534-1707," in Brendan Bradshaw and Morrill, eds., The British Problem: State-Fomation in the Atlantic Archipelago, c. 1534-1707 (Basingstoke, 1996), 12-14; Willy Maley, "Review," History Ireland 4 (Winter 1996): 53-55.

${ }^{32}$ Raymond Gillespie, "Explorers, Exploiters and Entrepreneurs: Farly Modern Ireland and Its Context, 1500-1700," in B. J. Graham and L. J. Proudfoot, eds., An Historical Geography of Ireland (London, 1993), 152. 
hesitant to make the turn toward the Atlantic and the other oceans recomsnended by Pocock. ${ }^{33}$ This is all the more remarkable in that historians of Colonial British America (to use Jack P. Greene and J. R. Pole's term) have increasingly relied on "Atlanticist" models for their historiography in the last two decades. ${ }^{34}$ There is, of course, nothing new in this. The admiring constitutionalism of Jeremy Bentham and Lord Bryce, or the navalist obeisance of Alfred Thayer Mahan, helped to forge channels of intellectual influence and interaction across the Atlantic throughout the nineteenth century. ${ }^{35}$ Yet, as Bernard Bailyn has recently noted, one major species of "Atlanticism" originated in American anti-isolationism during two world wars, particularly in the journalistic internationalism of Walter Lippmann and Forrest Davis and the anticommunist, Catholic universalism of historians like Ross J. Hoffman and Carlton Hayes. ${ }^{36}$ They forged their conception of an Atlantic community as a bulwark of Western civilization against Fascist and Communist barbarism, though also very much as an antidote to European integration, which history suggested could only be achieved by the force of a Napoleon or a Hitler: "To escape such a fate the British during the last four centuries have repeatedly fought world wars." ${ }^{37}$ The very tradition that these Atlanticists sought to uphold was being reconfigured by Christian supersessionists as "Judeo-Christian" at the same time, in some of the same circles, in response to the same threats, and in search of a similar consensus. ${ }^{38}$ When Hayes asked rhetorically, "The American Frontier-Frontier of What?" in his 1945 presidential address before the American Historical Association, the answer was unambiguous: "the Greco-Roman and Judeo-Christian tradition." ${ }^{3 y}$ Both Atlantic History and the Judeo-Christian tradition were shaped by similar conditions at their birth in the United States in the 1940s and have carried some vestigial features of their origins ever since.

The peculiar origins of this strain of Atlantic History in the United States may account for the initial reluctance of British historians to take the Atlantic model seriously, despite some scattered postwar attempts to teach the history of the United States not as "a separate national story to be laid arbitrarily alongside the national history of Great Britain, but an integral and vital part of the history of all

$3^{33}$ For example, none of the major collections of essays on the New British History covers any British territories, populations. or influences outside Britain and Ireland: Asch, Threc Nations-A Common History?; Grant and Stringer, Uniting the Kingdom?; Ellis and Barber, Conquest and Union; Bradshaw and Morrili, British Problem; I aurence Brockliss and David Eastwood, eds., A Union of Muliple Identities: The British Isles c. 1750-c. 1850 (Manchester, 1997); Bradshaw and Peter Roberts, eds., British Consciousne'ss and Identity: The Making of Britain, 1533-1707 (Cambridge, 1998); S. J. Connolly, ed., Kingdoms United? Great Britain and Ireland since 1500: Integration and Diversity (Dublin, 1998); except for Tony Claydon and Ian McBride, eds., Protestantism and National Identity: Britain and lreland, c. $1650-$ c. 1850 (Cambridge, 1998).

${ }_{34}$ Jack P. Greene and J. R. Pole, eds., Colonial British America: Essays in the New IIstory of the Early Modern Era (Baltimore, Md., 1984).

${ }^{3.5}$ H. I. A. Hart, "The United States of America," in Hart, Essays on Bentham: Jurisprudence and Political Theory (Oxford, 1982), 53-78; Edmund S. Ions, James Bryce and American Democracy 1870-1922 (London, 1968); Anders Stephanson, Manifest Destiny: American Expansion and the Empire of Right (New York, 1995), 84-87; Christopher Hitchens, Blood, Class, and Nostalgia: Anglo-American lronies (New York, 1990), chaps. 4-6.

36 Bernard Bailyn, "The Idea of Atlantic History," Itinerario 21) (1996): 19-44.

$\therefore$ Ross Hoffman, "Europe and the Atlantic Community," Thought 20 (1945): 29.

${ }^{3 *}$ Mark Silk, "Notes on the Judeo-Christian Tradition in America," American Quarterly 36 (1984): $66-70,83-85$.

39 Carlton J. H. Hayes, "The American Fronticr-frontier of What?" AHR 51 (January 1946): 215. 
those areas, European and American alike, which border upon the North Atlantic." 40 However, it cannot account for the continuing resistance among British historians to Atlantic History, when American historians have become so obviously indebted to British historiography. The work of Bernard Bailyn, Jack Greene, Ned Landsman, Susan O'Brien, David Cressy, David Hackett Fischer, Stephen Foster, Joyce Chaplin, James Horn, David Hancock, and Eliga Gould, among others, has amply revealed the necessity for historians of British America to attend to the economic, social, constitutional, intellectual, religious, and political history of Britain and Ireland in their studies of the polities of the northwestern Atlantic basin, especially in the period before $1783 .{ }^{41}$ Early modern British history has become indispensable for historians of colonial America: why, then, have British historians almost completely failed to join hands across the ocean with colonial Americanists? ?2 $^{2}$

Historians' categories have their costs. The very terms "early modern" to describe a period of British (and, more broadly, European) history and "colonial" to denominate a parallel period of American history indicate the incompatible master-narratives within which British and American historiography have existed for much of the twentieth century. Despite Greene and Pole's argument that America in the seventeenth and eighteenth centuries should be seen as part of the wider "Early Modern Era," this periodization has found little favor with Americanists. ${ }^{43}$ The narrative of modernity implicit in Europeanists' use of the designition "early modern" does not usually include empire among its defining features. ${ }^{44}$ Its central terms have been the rise of capitalism, individualism, and the middle class; the creation of the nation-state, controlled by centralized regimes with armies and bureaucracies at their disposal but limited by representative bodies and the rule

${ }^{40}$ H. Hale Bellot, "Atlantic History," History 31 (1946): 62.

41 Bernard Bailyn, The Ideological Origins of the American Revolution, $2 \mathrm{~d}$ edn. (Cambridge, Mass., 1995); Bailyn, Voyagers to the West: A Passage in the Peopling of America on the Eve of the American Revolution (New York, 1987); Bailyn and Morgan, Strangers within the Realm; Greene, Peripheries and Center; Jack P. Greene, Pursuits of Happiness: The Social Development of Early Modern British Colonies and the Formation of American Culture (Chapel Hill, N.C., 1988); Ned C. Landsman, Scotland and Its First American Colony, 1683-1765 (Princeton, N.J., 1985); Landsman, From Colonials to Provincials: Amcrican Thought and Culture, 1680-1760 (New York, 1997); Susan O'Brien, "A Transatlantic Community of Saints: The Great Awakening and the First Evangclical Network, 1735-1755," AHR 91 (October 1986): 811-32; David Cressy, Coming Over: Migration and Communication between England and New England in the Seventeenth Century (Cambridge, 1987); David Hackett Fischer, Albion's Seed: Four British Folkways in America (Oxford, 1989); Stephen Foster, The Long Argument: English Puritanism and the Shaping of New England Culture, 1570-1700 (Chapel Hill, 1991); Joyce E. Chaplin, An Anxious Pursuit: Agricultural Innovation in the Lower South, 1730-1815 (Chapel Hill, 1993); James Horn, Adapting to a New World: English Society in the Seventeenth-Century Chesapeake (Chapel Hill, 1994); David Hancock, Citizens of the World: London Merchants and the Integration of the British Atlantic Community, 1735-1785 (Cambridge, 1995); Eliga H. Gould, The Persistence of Empire: British Political Culture in the Age of the American Revolution (Chapel Hill, 1999). For a recent overview of the possibilities presented by this historiography, see Alison Games, "History without Borders: Teaching American History in an Atlantic Context," Indiana Magazine of History 91 (1995): 159-78.

42 J. C. D. Clark, "The Strange Death of British History? Reflections on Anglo-American Scholarship," Historical Journal 40 (1997): 787-809, offers a rather different set of answers to this question from that offered here.

${ }^{43}$ Greene and Pole, Colonial British America, subtitled "Essays in the New History of the Early Modern Era."

${ }^{44}$ This is also true of grand narratives like those of Michael Mann, The Sources of Social Power, 2 vols. (Cambridge, 1986); and Charles Tilly, Coercion, Capital, and European States, AD 990 1992, rev. edn. (Cambridge, Mass., 1992). 
of law; and, more broadly, the disenchantment of the world and the emergence of rationality under the sign of science. ${ }^{45}$ This broadly Weberian master-narrative owed a great deal to modernization theory, which had posited the postbellum trajectory of political, social, and economic development in the United States as a normative path to be followed by other "developing" countries. Curiously, though, this narrative of "American" modernity did not generate a preceding narrative of American "early" modernity. ${ }^{46}$ This is all the more remarkable in that the "discovery" of America, intercontinental migration, and the globalization of commerce once figured prominently in earlier, European models of modernity, from the sixteenth century to the $1950 \mathrm{~s}$, and had been central to the historical visions of David Hume and Adam Smith, Karl Marx and Otto von Bismarck. ${ }^{47}$ Like contemporary "colonial" Spanish America, British America evidently missed out on "early" modernity. ${ }^{48}$

It has been left to self-consciously post-modern counter-narratives to rediscover globalization, the "disembedding" of individuals effected by transnational capitalism (especially the slave trade), and the diasporic histories of pre-national peoples as aspects of modernity that could usefully describe features of the Atlantic world before the mid-nineteenth century. ${ }^{49}$ In this context, the work of Paul Gilroy on the formation of a "Black Atlantic" between the eighteenth and the twentieth centuries and Peter Linebaugh and Marcus Rediker's ongoing study of the creation of an "Atlantic working class" together offer a dynamic, circulatory, and interracial (albeit still somewhat provisional) model of the Atlantic world as a matrix of

45 On which, see Dean C. Tipps, "Modernization Theory and the Comparative Study of Societies: A Critical Perspective," Comparative Studies in Society and History 15 (1973): 199-226. Keith Thomas, "The United Kingdom," in Raymond Grew, ed., Crises of Political Development in Europe and the United States (Princeton, N.J., 1978), 41-99, provides a version of the modernization thesis as applied to Britain; for an outstanding account of such narratives and the historiography that has succeeded them in English (though specifically not British) history, see Peter Lake, "Retrospective: Wentworth's Political World in Revisionist and Post-Revisionist Perspective," in J. F. Merritt, \&d., The Political World of Thomas Wentworth, Earl of Strafford, 1621-1641 (Cambridge, 1996), 252-83.

4o Though for a pioneering attempt to apply modernization theory to early American history, see Richard D. Brown, "Modernization and the Modern Personality in Early America, 1600-1865: A Sketch of a Synthesis," Journal of Interdisciplinary History 2 (1972): 201-28; compare also Joyce Appleby, "Value and Society," in Greene and Pole, Colonial British America, 290-316; Appleby, "Modernization Theory and Anglo-American Social Theories," in Liberalism and Republicanism in the Historical Imagination (Cambridge, Mass., 1992), 90-123; Appleby, Lynn Hunt, and Margaret Jacob, Telling the Truth about History (New York, 1994), chaps. 2-3; Chaplin, Anxious Pursuit.

${ }^{47}$ Reinhart Koselleck, "Neuzeit': Remarks on the Semantics of the Modern Concepts of Movement," in Koselleck, Futures Past: On the Semantics of Historical Time, Keith Tribe, trans. (Cambridge, Mass., 1985), 241-44; David Arnitage, "The New World and British Historical Thought: From Richard Hakluyt to William Robertson," in Karen Ordahl Kupperman, ed., America in European Consciousness, 1493-1750 (Chapel Hill, N.C., 1995), 60-63. For a relatively recent example, sec A. L. Rowse, "Tudor Expansion: The Transition from Medieval to Modern History," William and Mary Quarterly, 3d ser., 14 (1957): 309-16, which starts from Bismarck's Eurocentric claim that the peopling of North America was "the decisive fact in the modern world."

4\$ Though for evidence that "early modern" is not applicable solely to Europe, witness the essays collected in "Early Modernities," Daedalus 127 (Summer 1998).

49 Benedict Anderson, "Exodus," Critical Inquiry 20 (1994): 314-27; James Clifford, "Diasporas," iil Clifford, Routes: Travel and Translation in the Late Twentieth Century (Cambridge, Mass., 1997), 244-77; Khachig Tölölyan, "Rethinking Diaspora(s): Stateless Power in the Transnational Moment," Diaspora 5 (1996): 3-34; Geoff Eley and Ronald Grigor Suny, eds., Becoming National: A Reader (New York, 1996); Robin Cohen, Global Diasporas: An Introduction (London, 1997). Robin Blackburn, The Making of New World Slavery: From the Baroque to the Modern, 1492-1800 (1.ondon, 1997), provides the most explicit account of how these processes contributed to the formation of "modernity" itself. 
modernity itself.50 This work also offers an alternative genealogy for Atlantic history that reaches back through Eric Williams's Capitalism and Slavery (1944) and W. E. B. Du Bois to William Blake and beyond, and thereby escapes the distorting compulsions behind the conception of a Euro-Atlantic community inherited from the beginnings of the Cold War. As Ned C. Landsman's essay in this Forum shows, the use of such "diasporic" models offers an illuminating alternative to narratives built around the concept of "ethnicity," especially when considering the outgrowth of the peoples of Britain and Ireland within the wider Atlantic world. ${ }^{51}$

Such comparative, postmodern, and diasporic models for the history of the Atlantic world challenge the relationships of dependency and marginality implied by the term "colonial" as a period of "American" history before the great caesura of 1783. "Colonial" carries the freight of the "Imperial School" of American historiography without its institutional framework or, more regrettably, its geographical expansiveness. This approach originated in the late nineteenth century, as an offshoot of transatlantic Anglo-Saxonism and the "germ theory" of institutional transmission. Even as J. R. Seeley was giving his lectures as Regius Professor in Cambridge in 1881-1882, the man soon to be his opposite number at Oxford, E. A. Freeman, was simultaneously touring the United States to recall the common racial and institutional ties that bound together two English peoples on either side of the Atlantic "as brethren in a higher brotherhood, born of one ancient stock, speaking one ancient tongue, sharers under different forms in one ancient freedom." 52 Such connections underlay the origins of professional medievalism in the United States, which, in the work of Charles Homer Haskins and Joseph Strayer, tied the ficld to a narrative of state building and institutional formation that lent particular weight to the history of "England": in Haskins's words, "English history is in a sense early American history." 53 In the hands of historians Charles McLean Andrews, George Louis Beer, and Herbert Levi Osgood, British history became fully part of early American history, as they revised the standard Bancroftian account of the American Revolution in favor of the imperial and institutional synthesis that would characterize their work as members of a distinctly "Imperial School" of early American historians. ${ }^{54}$ Although their emphasis on an extra-American context for

5n Paul Gilroy, "The Black Atlantic as a Counterculture of Modernity," in Gilroy, The Black Atlantic: Modernity and Double Consciousness (Cambridge, Mass., 1993), 1-40; Peter Linebaugh, "All the Atlantic Mountains Shook," Labour/Le travailleur 10 (1982): 87-121; Marcus Rediker, Between the Devil and the Deep Blue Sea: Merchant Seamen, Pirates, and the Anglo-American Maritime World, 1700-1750 (Cambridge, 1987); Linebaugh and Rediker, "The Many-Headed Hydra: Sailors, Slaves and the Atlantic Working Class in the Eighteenth Century,"Journal of Historical Sociology 3 (1990): 225-53; Jeffrey Bolster, Black Jacks: African-American Seamen in the Age of Sail (Cambridge, Mass., 1997).

5I Ned C. Landsman, "Nation, Migration, and the Province in the First British Empire: Scotland and the Americas, 1600-1800," AHR 104 (April 1999): 463-75; David Armitage, "The Scottish Diaspora," in Jenny Wormald, ed., The Oxford Illustrated History of Scotland (Oxford, forthcoming).

52 Edward A. Freeman, Lectures to American Audiences (Philadelphia, 1882), 10; Freeman, Some Impressions of the United States (London, 1883); Freeman, Greater Greece and Greater Britain; And, George Washington, the Expander of England: Two Lectures (London, 1886).

${ }_{53}$ Charles Homer Haskins, "European History and American Scholarship," AHR 28 (January 192.3): 215, quoted in Paul Freedman and Gabrielle M. Spiegel, "Medievalisms Old and New: The Rediscovery of Alterity in North Amcrican Medieval Studies," AHR 103 (June 1998): 683.

${ }_{54}$ Charles M. Andrews, "Amcrican Colonial History, 1690-1750," and Herbert L. Osgood, "The Study of American Colonial History," American Historical Association, Report for the Year 1898 (Washington, D.C., 1899), 47-60, 63-73; Wesley Frank Craven, "Historical Study of the British 
the undertanding of American history was salutary, their object of inquiry remained the colonies that would later make up the United States rather than the British Empire as a whole. This certainly coincided with the division of labor within contemporary British imperial history, which also separated the so-called "First" British Empire in the Americas from the "Second" British Empire in South Asia, Africa, and the Pacific. Each of these strains of historiograplyy has had lasting consequences for the possibility of writing both Atlantic histories of "America" and imperial histories of "Britain." The reaction against the Imperial School within American historiography rendered the consideration of the links between Britain and America unfashionable until the new wave of British-American history broke in the late $1960 \mathrm{~s}$, by which time social, economic, cultural, and religious interactions took precedence over political and institutional continuities. ${ }^{55}$ Meanwhile, British historiography maintained a separation between the history of the two supposedly distinct empires but treated both as extraterritorial histories divorced from the domestic history of Britain. ${ }^{50}$

THE REINTEGRATION OF IMPERIAL AND DOMESTIC IISTORY and the union of the New British History with Atlantic History could provide a historiography capable of eluding the pull of nationalist teleologies in both British and Amcrican history. Atlantic History potentially offers a transnational challenge to American particularism, ${ }^{57}$ while the New British History confronts the whiggish pieties of AngloBritish self-congratulation. However, if Atlantic History ignores the wealthiest and most numerous British colonies in the Caribbean ${ }^{58}$ and overlooks the territories that would later comprise the Canadian Confederation, it risks becoming merely the acceptable face of American (for which, read "United States of Americall") exceptionalism. Likewise, the New British History has been charged with becoming simply a more comprehensive means to explain the peculiarities and processes of

Empire," Journal of Modern History 6 (1934): 40-69; L. H. Gipson, "The Imperial Approacl 10 Early Amcrican History." in R. A. Billington, ed., The Reinterpretation of Early American History (San Marino, Calif., 1966), 185-99; Richard R. Johnson, "Charles McLean Andrews and the Invention of American Colonial History," William and Mary Quarterly, 3d ser., 43 (1986): 519-41; Peter Novick, That Noble Dream: The "Objectivity Question" and the American Historical Profession (Cambridgc, 1988), 80-84.

s.5 Jack P. Greene, "Beyond Power: Paradign Subversion and Reformulation and the Re-creation of the Early Modern Atlantic World," in Greene, Interpreting Early America: Historiographical Essays (Charlottesville, Va., 1996), 17-42.

56 For pointed protests against that separation, see Peter Marshall, "The First and Second British rimpires: A Question of Demarcation," History 49 (1964): 13-23; and Philip Iawson, "The Missing Link: The Imperial Dimension in Understanding Hanoverian Britain," Historical Joumal 29 (1986): 747-51; for conspicuous cfforts to overcome it, see the essays in Lawson, $A$ Taste for Empire and Glory: Studies in British Overseas Expansion, 1660-1800 (Aldershot, 1997).

${ }^{57}$ lan Tyrrell, "American Exceptionalism in an Age of International Hisiory," AllR g6 (October 1991): 1031-55; Joyce Appleby, "Recovering Amcrica's Historic Diversity: Beyond Exceptionalism," Joumal of American Histony 79 (1992): 419-31; Michael Kammen, "The Problem of American Exceptionalism: A Reconsideration," American Quarterly 45 (1993): 1-43.

58 Compare Jack P. Greene, "South Carolina and the Caribbean Connection," South Carolina Historical Magazine 88 (1987): 192--210; Andrew J. O'Shaughnessy, "The Stamp Act Crisis in the British Caribbean," Willam and Mary Quarterly, 3d ser., 52 (1994): 203-25; O'Shaughnessy, The Schism of Greater Britain: The American Revolution and the British Caribbean (forthcoming). My thanks to Dr. O'Shaughnessy for allowing me to read his manuscript before publication. 
English history (especially in the seventeenth century), with little obvious benefit for Scottish, Irish, or Welsh history. The most recent developments in both Atlantic History and the New British History have consciously taken account of these charges and have turned away from the dynamics of the "English" Civil Wars to the "Celtic dimensions of the British Civil Wars" and from the colonies that would become the United States to consider British North America in the widest sense. ${ }^{9}$ The next stage in the recreation of both British and American historiography in the period before the late eighteenth century should be to effect that rapprochement between the New British History and Atlantic History. Since the benefits of such methodological mingling have been perceived more often by historians of America than by those of Britain, ${ }^{60}$ the latter part of this essay will consider the potential impact of an Atlantic turn on British historiography of the early modern period.

"What did its great overseas extension, its heroic conquering and colonizing effort, its attempt to rule over and defend its far-flung possessions, mean for the history of Habsburg Spain?" asked J. H. Elliott in 1982.61 The parallel question has only just begun to be asked for Hanoverian Britain, but it has hardly been broached at all for the Stuart multiple kingdom of the seventeenth century. ${ }^{62}$ As in the case of the parallel inquiry into the "impact" of the New World on the Old (however mal posée this way of framing the question now appears to be), those who have asked the question at all have been either minimalists or maximalists. ${ }^{63}$ The minimalists stress the aggressive amnesia of eighteenth and nineteenth-century Britons: even though their lives were transformed by the colonial consumer goods, they remained insularly unaffected by the invisible influence of empire and cared little about the colonies. ${ }^{64}$ The maximalists meanwhile have argued for the determinative force of the imperial experience on British popular politics, literature, and culture. ${ }^{65}$ Both

${ }^{59}$ For the former, see, for example, Jane H. Ohlmeyer, Civil War and Restoration in the Three Stuart Kingdoms: The Career of Randall MacDonnell, Marquis of Antrim, 1609-1683 (Cambridge, 1993); and John R. Young, ed., Celtic Dimensions of the British Civil Wars (Edinburgh, 1997); for the latter, see, for example, Elizabeth Mancke, "Another British America: A Canadian Model for the Early Modern British Empire," Journal of Imperial and Commonwealth History 25 (1997): 1-36.

${ }^{60}$ As shown by Daniel Walker Howe, American History in an Atlantic Context: An Inaugural Lecture Delivered before the University of Oxford on 3 June 1993 (Oxford, 1993).

"I J. H. Elliott, "Spain and Its Empire in the Sixteenth and Seventeenth Centuries," in Elliott, Spain and Its World 1500-1700: Selected Essays (New Haven, Conn., 1989), 10.

${ }_{62}$ Notable exceptions are David Harris Sacks, The Widening Gate: Bristol and the Atlantic Economy, 1450-1700 (Berkeley, Calif., 1991); and Karen Ordahl Kupperman, "Needs and Opportunities: British Expansion," Itinerario 18 (1994): 130-36.

${ }_{63}$ Anthony Pagden, "The Impact of the New World on the Oid': The History of an Idea," Renaissance and Modern Studies 30 (1986): 1-11; J. H. Elliott, The Old World and the New, 1492-1650, 2d edn. (Cambridge, 1992); Elliot, "Final Reflections: The Old World and the New Revisited," in Kupperman, America in European Consciousness, 391-408.

64 Compare James Walvin, Fruits of Empire: Exotic Produce and British Taste, 1660-1800 (Basingstoke, 1997), with Linda Colley, "The Imperial Embrace," Yale Review 81, no. 4 (1993): 92-98; Jacob M. Price, "Who Cared about the Colonies? The Impact of the Thirteen Colonies on British Society and Politics circa 1714-1775," in Bailyn and Morgan, Strangers within the Realm, 395-436; P. J. Marshall, "Impcrial Britain," Joumal of Imperial and Commonwealth History 23 (1995): 379-94; and Jack P. Greene, "Empire and Identity from the Glorious Revolution to the American Revolution," in Marshall, Oxford History of the British Empire, Vol. 2: Eighteenth Century, 208-30.

${ }_{65}$ See especially James E. Gillespie, The Influence of Oversea [sic] Expansion on England to 1700 (New York, 1920); Jay Barrett Botsford, English Society in the Eighteenth Century as Influenced from Oversea [sic] (New York, 1924); Kathleen Wilson, "Empire, Trade and Popular Politics in MidHanoverian Britain: The Case of Admiral Vernon," Past and Present 121 (1988): 74-109; Wilson, "Empire of Virtue: The Impcrial Project and Hanoverian Culture c. 1720-1785," in Lawrence Stone, 
could, of course, be right, but only if the question were broken down further: for whom did the overseas extension of the Three Kingdoms have meaning, at what times, and why? How was nationhood defined by the experience of empirc? In particular, why did so many people in the metropolitan nations seem to remain resistant to the lure of empire and so indifferent to the experience of expansion, yet also find their conceptions of themselves quictly altered as "Britain" annexed aud conquered ever wider territories, populations, and markets?

A constrictedly archipelagic account of British history only reproduces such imperial introversion; it should instead be attempting to understand it. One approach is suggested by the classical conceptions of colonization that informed the first century of English settlement in the Western Hemisphere. ${ }^{67}$ Indeed, in the first century of transatlantic colonization, the classical tradition may have repressed imperial ambitions (at least among the significant proportion of the male population that had received a grammar-school education) more than it encouraged them, by transmitting skepticism about the wisdom of expansion and by constraining political theory to being literally the theory of the polis--the freestanding, autonomous, unitary community-rather than more complex forms of political organization such as unions and federations. ${ }^{\text {s }}$ The model of composite monarchy that has been so fruitfully used by recent historians to examine the dynamics of the Three Kingdoms was more often experienced than conceptualized by contemporaries, especially by those-in Ireland and Scotland particularly---who felt the force of English claims to unitary sovereignty, whether backed by crown, Parliament, or church. ${ }^{(13}$ However, it does have its uses as a heuristic device for understanding the continuities between the challenges of domestic and transmarine governance, in

ed., An Imperial State at War: Briain from 1689 to 1815 (London, 1994), 128-64; Wilson, The Sense of the People: Politics, Culture and Imperialism in England, 1715-1785 (Cambridge, 1995), 137-205, 237-84; Wilson, The Island Race: Englishness, Empire and Gender in the Eightrenth Century (London, forthcoming); Edward W. Said, Culture and Imperialism (Iondon, 1993); Felicity Nusslaum, Fomid Zones: Matcrnity, Sexuality, and Empire in Eighteenth-Century English Narratives (Baltimorc, Md.. 1995). It is notable in this connection that John Kerrigan's complaint, in "Birth of a Náison," London Review" of Books (June 5, 1997): 16--17, that students of "English" literature have failed to take a "Three Kingdoms" approach to their subject, was almost immediately answercd in David J. Baker, Between Nations: Shakespeare, Spenser, Manell and the Question of Britain (Stanford, Calif., 1997); Andrew Hadfield, Edmund Spenser's Irish Experience: Wilde Fruit and Savage Soyl (Oxford, 1997); Christopher Highley, Shakespeare, Spenser, and the Crisis in Ireland (Cambridge, 1997); and Willy Maley, Salvaging Spenser: Colonialism, Culture, and Identity (New York, 1997).

${ }^{\circ}$ P. J. Marstall, "A Nation Defined by 1impire, 1755-76," in Grant and Stringer, Uniting the Kingdom? 208-22; Marshall, "Empire and Opportunity in Britain, 1763-75," Transactions of the Royal Historical Society, 6th ser., 5 (1995): 111-28; Marshall, "Britain and the World in the Eighteenth Century: I, Reshaping the Empire," Transactions of the Royal Historical Society, 6th ser., 8 (1998): 1-18; H. V. Bowen, "British Conceptions of Global Empire, 1756-83," Journal of Imperial and Commonwealth History 26 (1998): 1-27; John M. MacKenzie, "Empire and National Identities: The Case of Scotland," Transacions of the Royal Historical Society, oth ser., 8 (1998): 215-32.

${ }^{67}$ Anthony Pagden, Lords of All the World: Ideologies of Empire in Spain, Britain and France $c$. 1500-6: 1800 (New Haven, Conn., 1995), chap. 1.

to Andrew Firmaurice, "Classical Rhetoric and the Promotion of the New Wor!d," Joumal of the History of Ideas 58 (1997): 221-44; David Armitage, "Literature and Empire," in Canny, Oxford History of the British Empire, Vol. 1: Origins of Empire, 99-123.

t9 John Morrill, "A British Patriarchy? Ecclesiastical Imperialism under the Early Stuarts," in Anthony Fletcher and Peter Roberts, eds., Religion, Culture and Society in Early Modem Britain: Ersays in Honour of Patrick Collinson (Cambridge, 1994), 209-37; Canny. "Irish, Scottish and Welsh Responses to Centralisation." 147-69. 
order to connect the history of the Atlantic world more firmly to the problematics of early modern European history. ${ }^{70}$

The New British History has expanded, but also has not entirely abandoned, the statist and institutional perspective of English Whig historiography; even the historiography of the Anglo-British state must admit the shaping force of the imperial experience, both within and beyond Britain and Ireland. This reunion of the history of the state with the history of empire is one positive legacy to be taken from Seeley, for whom all history was the history of the state, of which the empire was but the extension. ${ }^{71}$ Seeley's assumption that the empire exported the characteristics of the "English" state can be turned around in order to examine how the experience of expansion colored the growth of the state. The recent work of Robert Bliss has restored the American colonies to the context of English politics (although the larger, British dimension of their political salience is overlooked); David Ransome has emphasized the contribution of the disputes over the Virginia Company to the breakdown of consensus in the English Parliament of 1624; Karen Kupperman's reconstruction of the continuities between the activities of the Providence Island Company in the $1630 \mathrm{~s}$ and the overlapping personnel of the parliamentary "Middle Group" in the 1640s has made the English Civil War partly appear to be the pursuit of the colonial undertakers' aims by other means; and Mary K. Geiter has firmly linked the foundation of Pennsylvania to the political horse-trading of the Exclusion Crisis. ${ }^{72}$ Seventeenth-century English men and women were evidently not as insular as later historians might have believed; the demands of extending the nation oceanically tested their political imaginations, just as international conflict in Europe did. ${ }^{73}$

The findings of these scholars show the necessity of bringing the colonies into a pluralist account of the British Civil Wars, to see, for instance, how "British" populations outside the archipelago fought their own "American Civil Wars."74 Activities in the Caribbean shaped the politics of the Interregnum, as the hostile response to the failure of Oliver Cromwell's "Western Design" may have been responsible for his decision to refuse the crown in 1658 , and certainly provided a focus for discontent that struck at the very heart of the Protectorate and its policy

70 Jack P. Greene, "Negotiated Authorities: The Problem of Governance in the Extended Polities of the Early Modern Atlantic World," in Greene, Negotiated Authorities: Essays in Colonial Political and Constitutional History (Charlottesvillc, Va., 1994), 1-24, is a pioneering attempt to forge this connection; meanwhile, Peter N. Miller, Defining the Common Good: Empire, Religion and Philosophy in Eighteenth-Century Britain (Cambridge, 1994), has suggested the appropriate carly modern intellectual framework within which such problems were thinkable for contemporaries.

71 Seeley, Expansion of England, 11, 38.

${ }^{72}$ Robert M. Bliss, Revolution and Empire: English Politics and the American Colonies in the Seventeenth Century (Manchester, 1990); "The Parliamentary Papers of Nicholas Ferrar, 1624," David R. Ransome, ed., Camden Miscellany, 33, Seventeenth-Century Political and Financial Papers (Cambridge, 1996), 1-104; Karen Ordahl Kupperman, Providence Island, 1630-1641: The Other Puritan Colony (Cambridge, 1993); Mary K. Geiter, "The Restoration Crisis and the Launching of Pennsylvania, 1679-81," English Historical Review 112 (1997): 300-18.

${ }_{73}$ As revealed amply in Steven C. A. Pincus, Protestantism and Patriotism: Ideologies and the Making of English Foreign Policy, 1650-1668 (Cambridge, 1996).

${ }^{74}$ Compare Robert Brenner, Merchants and Revolution: Commercial Change, Political Conflict, and London's Overseas Traders, 1550-1653 (Princeton, N.J., 1993); work in progress by Carla Gardina Pestana will illuminate the American side of the mid-seventeenth-century conflicts. 
ambitions, domestically and diplomatically. ${ }^{75}$ The character of the post-Restoration state was partly shaped by the duke of York's experience as proprietor of New York and architect of the Dominion of New England. ${ }^{76}$ The role of the colonies in the patronage system has been brought to light by Stephen Saunders Webb, although his thesis perhaps reveals more that the empire helped make a late seventeenthcentury "opportunity state," espccially for former military officers, than that it was the creature of "garrison government."77 Finally, the very formation of the British state itself, by the Anglo-Scottish Union of 1707 , was an event incomprehensible without its imperial context, since the compulsions that drove the Scots and the English together were cast on a global screen-from the Isthmus of Panama to the Low Countries - and the union provided an alternative to an independent colonial empire for the Scots, who had come late to the arguments of commercial reason of state. ${ }^{78}$ Seeley saw what later historians have largely forgotten: the great process of the seventeenth century had been "the internal union of the three kingdoms" between the accession of James VI to the English throne in 1603 and the Anglo-Scottish Union of 1707 ; alongside that process, and growing out from it, "was the creation of a still larger Britain comprehending vast possessions beyond the sea." 79

The greatest potential for the convergence of British and American history lies in the study of the eighteenth century, where the reigning, albeit frequently competing, syntheses of the period by J. C. D. Clark, Paul Langford, John Brewer, and Linda Colley can all be linked to developments in American historiography. ${ }^{80}$ Colley's Britons has been accompanied by Edward Countryman's Americans, Clark's English Society by the opening chapters of Gordon Wood's Radicalism of the American Revolution, and Richard L. Bushman's Refinement of America by Brewer's Pleasures of the Imagination. 81 The receptivity of historians of eighteenth-century America to the British dimension of their subject means that some of this work has

${ }^{75}$ Blair Worden, "Oliver Cromwell and the Sin of Achan," in Derek Beales and Geoffrey Best, eds., History, Society and the Churches (Cambridge, 1985), 125 -45; Karen Ordahl Kupperman, "Errand to the Indies: Puritan Colonization from Providence Island through the Western Design," William and Mary Quarterly, 3d ser., 44 (1988): 70-99; David Armitage, "The Cromwellian Protectorate and the Languages of Empire," Historical Joumal 35 (1992): 531-55.

76 An adequate biography of the duke of York, as proprietor of New York, King James VIl of Scotland, and King James II of Ireland, as well as James II of England, is an important need to be filled by the New British History, although W. A. Speck, Reluctant Revolutionaries: Englishmen and the Revolution of 1688 (Oxford, 1988), 11-13, does offer some hints about the role of James's proprictorship in exciting suspicions about his incipient authoritarianism.

7 Stephen Saunders Webb, The Governors-General: The English Army and the Definition of Empire. 1569-168I (Chapel Hill, N.C., 1979); Webb, Lord Churchill's Coup: The Anglo-American Empire and the Cilorious Revolution Reconsidered (New York, 1995).

75 John Robertson, "Union, State and Empire: The Union of 1707 in Its European Setting," in Stone, Imperial State at War, 224-57; David Armitage, "The Scottish Vision of Empire: Intellectual Origins of the Darien Venture," in John Robertson, ed., A Union for Empire: Political Thought and the British Union of 1707 (Cambridge, 1995), 97-118.

${ }^{74}$ Seeley, Expansion of England, 13.

5. C. D. Clark, English Society, 1660-1832: Ideology, Social Structure and Political Practice during the Ancien Regime (Cambridge, 1985); John Brewer, The Sinews of Power: War, Moncy and the English State, 1688-1783 (London, 1989); Paul Langford, A Polite and Commercial Pcople: England 1727-1783 (Oxford, 1989); Linda Colley, Britons: Forging the Nation, 1707-1837 (New I-Tuven, Conn., 1992).

${ }^{8}$ Edward Countryman, Americans: A Collision of Ilistories (New York, 1996); Gordon Wood, The Radicalism of the American Revolution (New York, 1992), chaps. 1-5; Richard L. Bushman, The Refinement of America: Persons, Houses, Cities (New York, 1990); John Brewer, The Pleasures of the 
already been absorbed into an Atlantic historiography, although the compliment has only just begun to be repaid by British historians.82 As Edmund Morgan suggested forty years ago, the historiography of the American Revolution has always been peculiarly dependent on British history for its various explanatory frameworks. American historians are perhaps now long past the Namierite, marxisant, and localist explanations Morgan took to be the major shaping arguments in his own time. ${ }^{83}$ Indeed, following Morgan's lead, T. H. Breen has recently taken explicit inspiration from the work of Brewer and Colley to suggest that the British state in the eighteenth century, with its lean and efficient administrative apparatus, extraordinary capacity to raise revenue and make war, and above all the aggressive patriotism it projected, "forced the Americans to leap out of history to defend colonial and human equality on the basis of timeless natural rights." 84

The absorption of the American war and revolution into the internal history of Britain-foreshadowed by Seeley, who thought it "an event ... on an altogether higher level of importance than almost any other in modern English [sic] history"has shown how imperial history can be rcintegrated into domestic history, even if British historians of the period before the late eighteenth century otherwise seem to remain largely unaware of the bridges thrown across to them by historians of the western sector of the British Atlantic world. ${ }^{85}$ The United Kingdom of Great Britain and the United States of America were both political unions created in the context of international war during the eighteenth century, their fictive nationalisms were generated by many of the same conflicts, and the political-rather than ethnic, linguistic, or historical--categories of citizenship within each state make them comparable as few other states are. This fact alone should encourage historiographical convergence, even more so because such a comparison denies exceptionalism and disrupts cherished nationalist teleologies.

Inagination: English Culture in the Eighteenth Century (London, 1997); compare also David S. Shields, Civil Tongues and Polite Letters in British America (Chapel Hill, N.C., 1997).

82 The major cxamples of British repayment of this debt are Clark, Language of Liberty; and Colley, Significance of the Frontier in British History.

X:3 Edmund S. Morgan, "The American Revolution: Revisions in Need of Revising," William and Mary Quarterly, 3d ser., 14 (1957): 3-15.

${ }^{4}$ T. H. Breen, "Ideology and Nationalism on the Eve of the American Revolution: Revisions Once More in Need of Revising," Joturnal of American History 84 (1997): 13-39.

8.5 Seeley, Expansion of England, 117; Dalphy I. Fagerstrom, "The American Revolution in Scottish Opinion, 1763-83" (PhD dissertation, Edinburgh University, 1951); J. H. Plumb, "British Attitudes to the American Revolution," in Plumb, In the Light of History (London, 1972), 70-87; John Derry, English Politics and the American Revolution (London, 1976); Colin Bonwick, English Radicals and the American Revolution (London, 1977); J. G. A. Pocock, ed., Three British Revolutions: 1641, 1688, 1776 (Princeton, N.J., 1980); James Bradley, Popular Politics and the American Revolution in England: Petitions, the Crown, and Public Opinion (Macon, Ga., 1986); John Sainsbury, Disaffected Patriots: London Supporters of Revolutionary America 1769-1782 (Kingston, Ontario, 1987); Stephen Conway, The War of American Independence, 1775-1783 (London, 1995), 187-214; Pocock, "Empire, State and Confederation: The War of American Independence as a Crisis in Multiple Monarchy," in Robertson, Union for Empire, 318-48; Eliga H. Gould, "American Independence and Britain's Counterrevolution," Past and Present 154 (Fcbruary 1997): 107-41; H. T. Dickinson, ed., Britain and the American Revolution (Harlow, 1998); Gould, "Virtual Nation." 
Is "Greater Britain" therefore a useful category of historical analysis? "Greater British" history can be a prophylactic against other, more partial, histories that dissociate the processes of nation making at all points in the North Atlantic from those of state formation and cmpire building. By acknowledging the constitutional primacy of the British state (after 1707, at least), it would recognize the relations of power within the early modern British Atlantic world and draw attention to the cultural, economic, and emotional bonds that tied inhabitants of that world together as Britons in the broadest sense. Law, politics, and economics, as well as culture, religion, and social order, shaped and defined relationships between the Atlantic archipelago and the Western Hemisphere, from Central America and the Caribbean to Cape Breton, and from the Leeward Islands to the Oregon Territory. Both the extent and the limits of those relations need to be more closely defined if the full usefulness of Greater Britain as an analytical category can be realized. The history of "colonial America" can thereby be seen as an arena of internal comparisons just as much as the history of "early modern Britain." I ike another "useful category of historical analysis," "Greater Britain" reveals seemingly fixed and determinate terms to be "at once empty and overflowing ... Empty because they have no ultimate, transcendent meaning. Overflowing because even when they appear to be fixed, they still contain within them alternative, denied, or suppressed definitions." 86 "Britain" and "America" are both empty and overflowing in parallel ways: "empty" because not defined by anything other than the precisely localized, contextual impulses of distinctly earthbound nationalisms; "overflowing" because of the multiplicity of competing, repressed, or ignored histories each contains within it.

The New British History and Atlantic History are each, in their own ways, transnational historiographies. In their stress on geographical and political pluralism, their escape from the boundaries of nation-states, and their insistence on the contingency and fluidity of historical processes, each offers liberation from the categories of national history. However, if they remain in isolation from one another, they risk perpetuating merely ampler species of parochialism, within which the New British History can become a cloak for the "cloven hoof" of Anglocentrism, ${ }^{87}$ or Atlantic History simply the kinder, gentler form of American exceptionalism. Just as Atlantic History needed to be freed from some of the distorting influences of Cold War, NATO historiography, so the New British History must avoid the lingering taint of anti-Europeanism bred into its bones in the early $1970 \mathrm{~s}$. The alliance between the New British History and Atlantic History could therefore become the first step toward novel integrative histories of "Greater Britain," as well as new comparative histories of "Atlantic America" and "Atlantic Europe." that means, it might be possible to show that "British" history did not always

86 Joan Wallach Scott, "Gender: A Useful Catcgory of Historical Analysis," in Scott, Gender and the Politics of History (New York, 1988), 49, orig. pub. in AHR 91 (December 1986): 1053-75.

${ }^{87}$ Conrad Russell, “John Bull's Other Nations," Times Literary Supplement (March 12, 1993): 3-4.

${ }^{8 *} \mathrm{D}$. W. Meinig, The Shaping of America: A Geographical Perspective on 500 Years of History, Vol. 1: Atlantic: America, 1492-1800 (New Haven, Conn., 1986); E. Estyn Evans, "Atlantic Europe: The Pastoral Heritage," in Evans, Ireland and the Atlantic Heritage: Selected Writings (Dublin, 1996), 59-61. 
happen in Britain, or only to Britons, just as "American" history was not always the creation of Americans, nor did it take place solely in the Americas. ${ }^{89}$

89 For the benefits of both integration and comparison in the history of the Americas in the early modern period, see J. H. Elliott, Do the Americas Have a Common History? An Address (Providence, R.I., 1998).

David Armitage is an associate professor of history at Columbia University, where he has taught British history and the history of social and political thought since 1993 . He was previously a rescarch fellow of Emmanucl College, Cambridge, where he completed his PhD with Quentin Skinner. Armitage has cdited Bolingbroke: Political Writings (1997) and Theories of Empire, 1450-1800 (1998), and co-cdited Milton and Republicanism (1995). His study The Ideological Origins of the British Empire will be published next year by Cambridge University Press. 